\title{
Physical Analysis of Formal and Informal Integration in Urban Riverside Settlement
}

\author{
${ }^{1}$ NOOR HAMIDAH, ${ }^{2}$ R. RIJANTA, ${ }^{3}$ BAKTI SETIAWAN, ${ }^{4}$ MUH. ARIS MARFAI \\ 1,2,4 Fakultas Geografi, Universita Gadjah Mada, Jl. Sekip Utara Bulak Sumur Yogyakarta, Indonesia, \\ ${ }^{3}$ Fakultas Teknik, UGM Indonesia \\ email address: ${ }^{1}$ noor.hamidah@mail.ugm.ac.id, ${ }^{2}$ rijanta@ugm.ac.id, \\ 3bobi.setiawan@yahoo.com, ${ }^{4}$ arismarfai@yahoo.com
}

\begin{abstract}
The concept of this research toward sustainability development, it focuses on availability of human settlement. One of the primary goals in human settlement in a city development. Most of settlement in Indonesia is located close to the river. The main function of river is living orientation, transportation, and settlement. The riverside area is developed to be a city with the rapid urban settlement along a riverside area, such as informal settlement inside formal settlement. The objective of this research is to analyze of the pattern of physical integration between formal and informal settlements in Kahayan Urban Riverside settlement. The research located in Kahayan urban riverside area, it called Kampung Pahandut, Central Kalimantan Province, Indonesia. Research method used a mix-used method based on has three phase: prilimanary, field observation, post field observation with 100 samples. The output of research is descriptive model of physical integration of settlement, it can be support settlements in those urban riverside area towards sustainable development.
\end{abstract}

Keywords: analysis, physical integration, formal, informal, settlement, urban

\section{Introduction}

Indonesia is currently facing a problem on providing the adequate formal housing to the poor by the public and the private sectors. Therefore informal settlement or so called "Kampung" in Indonesia is increasingly popular, as it has met the basic needs of millions of urban dwellers. The flexibility and the variety of housing arrangements within the Kampung have enabled millions of the migrants to find the cheap accommodations either permanently or temporarily. In Indonesia, Kampung has a long history usually located beside the riverside and nearby the main centre of cities with good access to fresh water in the river and jobs in the urban areas. Due to high pressure on the economic development in these Kampungs such as development of tourist centres, the urban dwellers often get threaten from the evictions or removed from the areas.

Indonesia government is trying to enhance the effectiveness of the formal settlement, by providing access to the basic elements of housing development, particularly land and finance, but the results tend to be limited. The Kampung Improvement Program (KIP) is one of Indonesia government program helped the poor people to receive a basic degree of minimum housing infrastructure such as road, water supply, and electricity (Setiawan, 1998). One important characteristic of Kampung is not clear between formal and informal (Setiawan, 1998). Kampung has a local dynamic people to improve physical, economic, and social access to the city, that is called dynamics of Kampung. The research limitation explored only formal and informal integration by physical aspect of kampung in urban riverside settlement. The research is used case study in Kampung Pahandut, Pahandut District, Palangka Raya, Central Kalimantan Province, Indonesia (see Figure 1). Kampung Pahandut is an old kampung with location along Kahayan River. The research question is how to explain the physical formal and informal integration

Received: November 09, 2016, Revision: April 12, 2017, Accepted: May 19, 2017

Print ISSN: 0215-8175; Online ISSN: 2303-2499.

Accredited by DIKTI. SK Kemendikbud, No.040/P/2014, valid 18-02-2014 until 18-02-2019, Indexed by DOAJ 
by involved community outside formal planning? How to examine without obtaining formal-legal status of Kampung in regard to improve their settlement? Is Kampung people gained the resources and security necessary to develop and improve their settlements? Based on research question the objective of this research is to explain the physical formal and informal integration by involved community outside formal planning. Further it examines without obtaining formal-legal status of Kampung in regard to improve their settlement. Kampung people gained the resources and security necessary to develop and improve their settlements. The purpose of this research is to present local dynamic of Kampung Pahandut by using analysis of physical formal and informal in urban development and an approach to bring these Kampung into the formal planning process without evicting the urban dwellers.

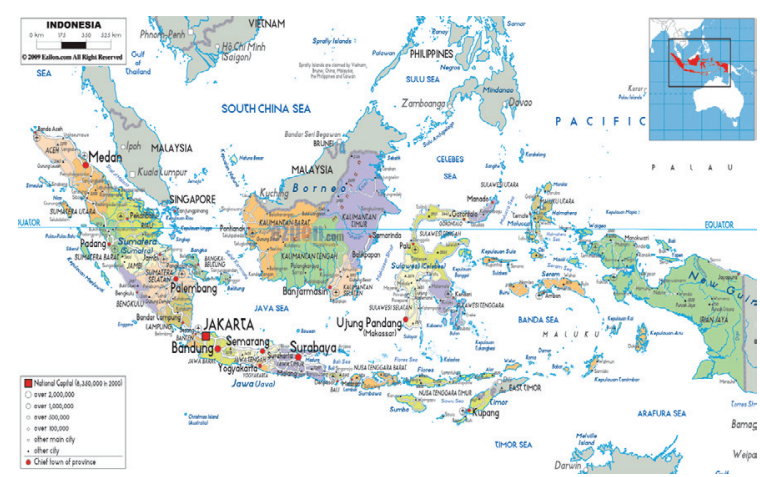

Figure 1. Indonesia Map (Sumber: http:// www.gambar-peta-indonesia.html)

The research finding shows that the Indonesian government needs to treat housing and kampung issues as part of a broader social welfare policy and should create more transparent and fairer mechanisms to guarantee equal opportunities for access to urban resources and decision making processes. This study argues that Kampung people and their local institutions (less formal organization), that can be built social capital the Neighbourhood Association (Rukun Tetangga/RT) and Community Association (Rukun Warga/RW). Local institution has a potential for playing more active roles in the dynamic process of urban planning and housing development. Finally, this study suggests that the government's approaches to the promotion of more formalized and regulated urban planning and housing development of Kampung should be carefully to assess the social and cultural in the contexts of Indonesian society.

\section{Conceptual Framework: Urban Dynamic of Kampung}

This research sees informal settlement as a spatial assemblage, emerging as a result of unauthorized tenure acquisition by which built form is employed as a tool of territorial claim. The process of territorial claim can be massive yet rapid, or incremental yet lengthy. Some informal settlements in South America emerged as a result of planned massive invasion that could take place in one day (De Soto, 1989), while with others, example of Kampung in Indonesia mostly lies on riverside area with the process took years to initiate (Rahardjo, 2010). Both types have had impacts on the morphology of the built environment. The continuity and change of settlement's morphology can therefore be seen as a way of reading the process of tenure acquisition and stabilization.

This paper try to demonstrate how morphological mapping can help us understand the spatial dynamic of informal settlement, and how it links to tenure attainment. The first section discusses the meaning of secure tenure in the context of informal development, and the second looks at the role of built forms in tenure claim and stabilization. The third section discusses how morphological mapping reveals the dialectics of built form and tenure of a Kampung.

\section{Tenure Security}

Tenure security is broadly understood as 'the right of all individuals and groups to effective protection by the state against forced evictions' (UN-Habitat, 2003) T To some extent, such as a notion contradicts the role of the state as the main actor in forced eviction. Therefore, the notion of 'effective protection' often occurs as a protective system developed by the community through various forms of tenure negotiation with authority, rather than a system developed and implemented by the government. The development of protective systems by the community characterizes the development of informal settlement.

'Informal settlement', 'slum', and 'squatter settlement' are often used loosely and interchangeably in the discourse of lowincome housing. 'Informal settlement', 'slum', and 'squatter settlement' is linked with the way in which the tenure system operates within a specific context (Davis, 2006; Perlman, 2004). Slum and informal settlement are two distinct terms frequently interchanged without noticing the difference. Slum is often 
associated with squalid conditions as a result of serious lack of adequate infrastructure to support decent living, while informal settlement involved lack of tenure and control of planning, design, and construction. A formal/ informal of tenure illustrates a legalist view of tenure characteristics in human settlements. 'Slum' mainly denotes the physical conditions of the built environment and does not correlate with tenure issues (Rahardjo, 2010).

The UN defines security of tenure as the state's protection of citizens against forced eviction De Soto's (1989) argument mentioned above suggests that in informal settlement tenure is gained through a gradual non-standard process, which results in various forms of tenure system. These facts tend to be oversimplified by "the widespread designation of all urban settlement processes into formal and informal" (Payne 1997:30), but there are at least six types of tenure acquisition in informal settlement, namely de facto security, official recognition, land rental, occupancy and use rights, communal or cooperative ownership, and customary ownership (Payne 1997:31-34).

\section{Built Form}

Tenure in informal settlement occurs as a result of territorial claim, which involves the exercise of power. Invasion of vacant state land by squatters usually takes place when the land is governed in a disorderly manner. This lack or absence of a state's power to control property allows squatters to carry out territorial claim. Such a power contestation partially corresponds to what Dovey (1999) termed 'power over', which he defines as "the power of one agent (or group) over another, the power to ensure the compliance of the other with one's will" (Dovey 1999: 10). In rapid land invasion by a group of squatters, such as the case in Peru (De Soto, 1989), the power of massive planned invasion by squatters surpassed the state's capacity to immediately react; while in gradual invasion, which is usually carried out by individuals, the process is lengthy, since these invaders arrive separately and tends to be unorganized. Consolidation of power occurs when they reach sufficient population to establish a social network, by which they negotiate for a more secure tenure.

Both models, rapid and gradual invasions do not see ownership as a pertinent issue in their early stages. What these people are most concerned with is the capacity to control over territory, which conforms to Habraken's notion that "Ownership is not necessarily congruent with control" (Habraken 2000: 37). The capacity to maintain control over property ensures one's security of tenure Informal settlements, this requires the role of built forms. Squatters demarcate their territory by at least laying out markers then appropriate them until reaching a sufficient stage to dwell. The continuity and change of these built forms reflect the progress and constraints in tenure stabilization, which can be best observed by means of morphological mapping.

\section{Morphological Mapping}

Urban morphology is a study of human habitat, which basically looks at the urban forms in terms of building, open spaces, plot, and street. These elements may be examined through four levels of resolution: building and plot, street and block, city, and region (Moudon, 1997). Morphological change is a result of "a cycle of reaction between form and function" (Conzen 1981: 105).

Morphological maps presented in this paper put urban forms in the level of city as well as street and block of the selected case study. Unlike the conventional morphological mapping, these maps look beyond Conzen's notion of 'form and function' dialectics. They use the visualization of urban morphology as a tool to reveal the hidden characters of informal settlement, such as changes of neighbourhood boundary and households' tenure situation. The mapping was carried out through a combination of field survey, aerial photograph review, interview of some key informants, and archival study.

\section{Research of Methodology}

Research method uses mixed method, qualitative and qualitative research (Groat et $a l, 2000)^{13}$. The location of research is a capital city of Central Kalimantan Province, Indonesia, namely Palangka Raya. Case study selected by first kampung of Palangka Raya, namely 'Kampung Pahandut' located along Kahayan river (see Figure 2). There is only one district which located close to Kahayan urban riverside area called Pahandut subdistrict. The total area of Kampung Pahandut is $950 \mathrm{ha}$ or $9,5 \mathrm{~km}^{2}$ with the total population is 85.591 household (Palangka Raya Central Statistic Agency, 2014). The boundary of administrative of Kampung Pahandut consist of: (1) the north is Pahandut Seberang 
village; (2) the east is Tanjung Pinang village; (3) the south is Panarung village; (4) the west is Langkai village. Selected sample refer to case study of Kampung Pahandut with total sample 100 head household.

We are doing this research with ten research assistants were employed in the data collection. All of research assistants are students of Architecture Study Program of Department of Architecture of Faculty of Engineering of Palangka Raya University. A series of phases of activity is divided into three (3) phases, namely: (1) The first stage is the preparation of the study is the initial activity carried out to map the location of research is the mapping of points of potential physical integration, in Kampung Pahandut, District Pahandut. (2) The second stage is the field survey through field observation and structured interviews with neighbour head (Kepala Keluarga/KK) of 100 neighbour head in Kampung Pahandut. (3) The third stage is the post-fieldwork that data processing is done after the field activities focus on the formal and informal integration.

Exploration in this study selected by the first community association is called Rukun Warga/RW (RW-21), that is consist of RT (neighbourhood association) from RT-1, RT-
2, RT-3 and RT-4. The study was conducted to observe in the field and interviews with respondents household heads in each RT and in each RW located in a Kahayan urban riverside settlement, to know it is detailed data of the formal and informal physical development.

\section{Result}

This research found three sub topics discusses: (1) security of tenure; (2) built form and territorial claim; and (3) mapping of morphological. Three sub topics will connect to physical integration of formal and informal in settlement (Doxiadis, 1968) focus on: (1) nature (land); (2) network (infrastucture); (3) shell (settlement). Physical integration found three important aspects to improve Kampung into urban planning, there are: (1) security of tenure; (2) built form and territorial claim; and (3) mapping of morphological.

The first, de facto security of tenure, is gained as a result of tolerated squatting (Payne 1997). In the cities of Indonesia, the lengthy process of spatial planning has often led to a delay in transforming such planning into regulations, which gives adequate time to the squatters to stabilize their territorial claim by improving their shelter (see for example

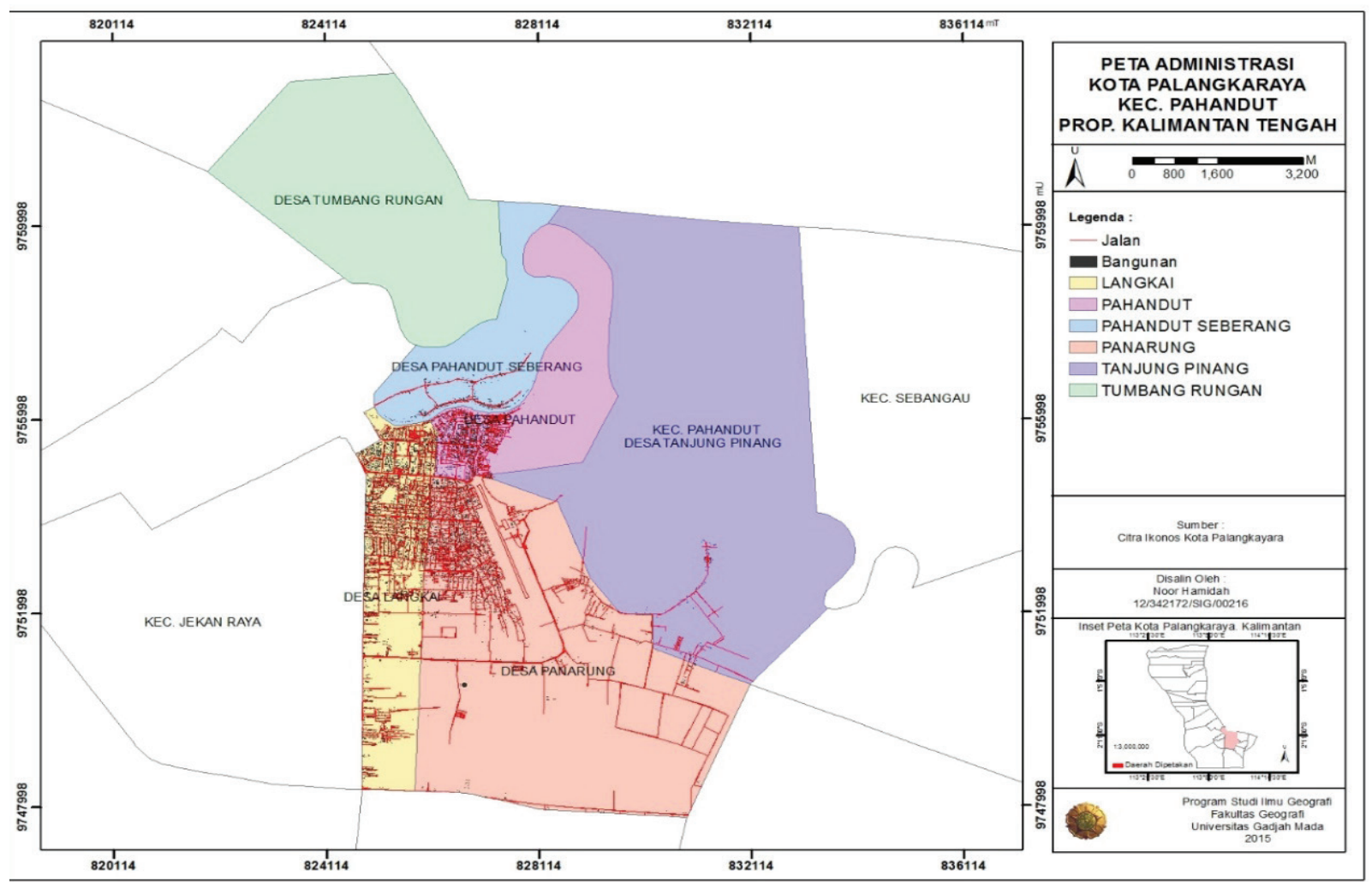

Figure 2. The Location of Research in Kampung Pahandut, Palangka Raya City, Indonesia source: google earth, 2014 
Khudori, 2000). This improvement is often ac celerated by slum upgrading initiatives supported by both local government and NGOs that disregard the issues of legal tenure.

Land is a part of security of tenure. Kampung Pahandut is located in the bank of the River Kahayan. Kampung Pahandut is an urban Kampung in Palangka Raya City, Central Kalimantan Province of Indonesia. The downstream part is the lowland recipient of the surface water flow, when the tidal flood will occur, however when the water will recede the river water (Riwut, 1979). The architectural side found that the Kahayan riverside building follow the contour, topography and adaptation patterns of river. There are two model of settlement based on the topography, there are namely pillar house and raft house. The settlement in Kampung Pahandut $80 \%$ location in land called pillar house and $20 \%$ settlement is location on water (see Figure 3 ).

Struyk (1990) argue that $80 \%$ of Kampung 'informal settlement'. Based on Struyk (1990) state the settlement cannot show the legal status of land. The illegal land in urban riverside settlement can be shown by topography. The raft house can be show by non permanent building on water, (there is no land and no legal land). The pillar house is a semi permanent building, the owner can show the status of land by a local certificate with local authority by head village of Kampung Pahandut. This research can be found that physical integration by land. The physical integration is one example to show security of tenure 'legal, semi legal or illegal' of land, It can be found by topography (on water or in land) and certificate of land.

Field survey found that kampung people argue that is only through illegal mechanism that they can have access to resources, particularly land. Since the formal land market in Palangka Raya city does not work very well, and land prices and land speculation tend to be uncontrolled, there is only a limited chance for urban poor to get access to land through this formal market. In this situation, it is clear that the only alternative for them is to violate the law by the illegal invasion of public land.

The second type, can be obtained through "default over time, or by the active efforts of the residents, developers, and local politician" (Payne 1997:31). The case study selected for this paper, is an

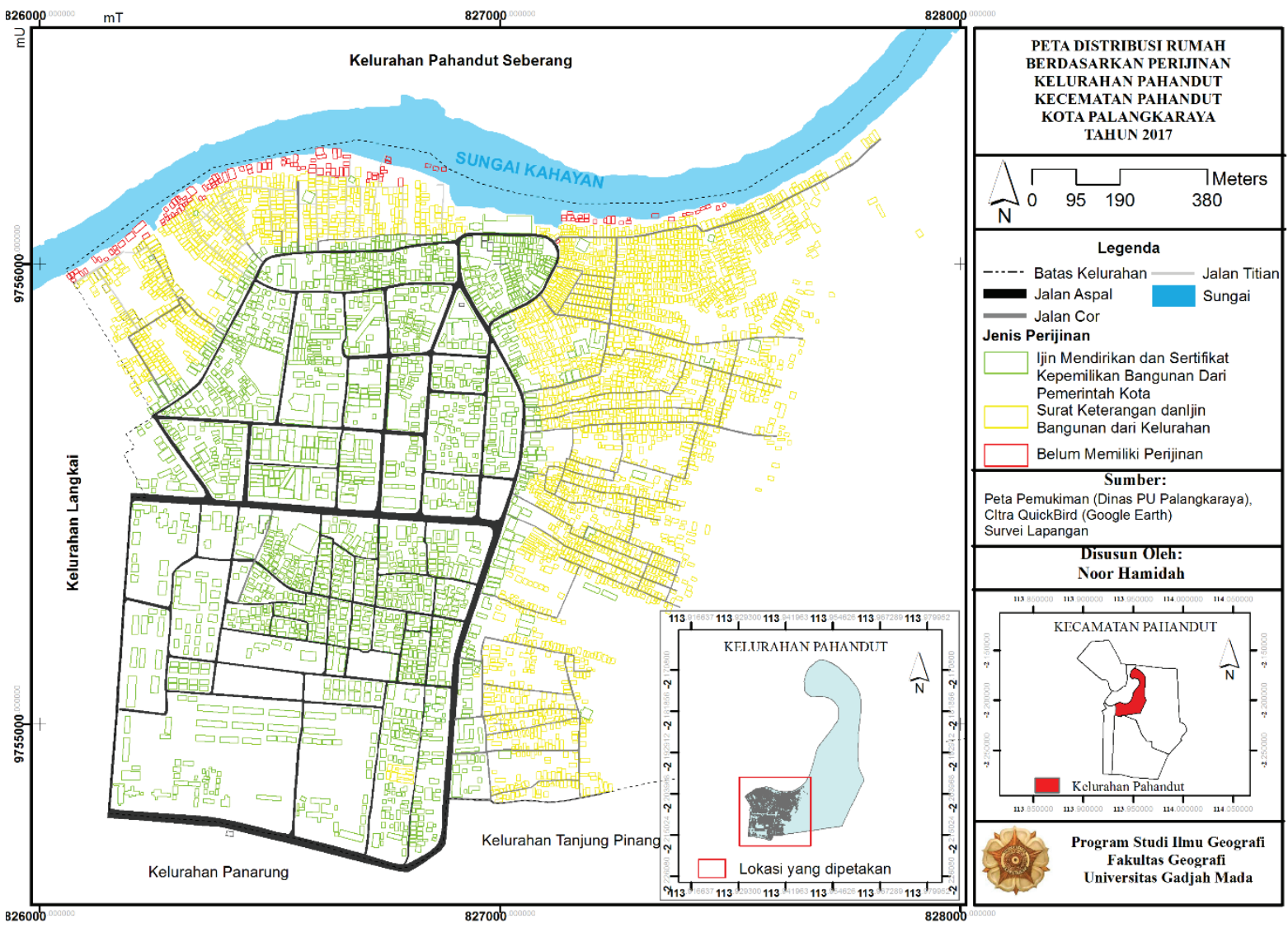

Figure 3. Map of land status red is a illegal land (raft house/ red rectagle), semi legal (pillar house/ yellow rectagle), legal (permanent house/ green rectagle) (source: field observation, 2016 drawing by arc Map 3.10.1) 
example. A neighbourhood (RT) in Kampung Pahandut (Table 1), obtained administrative authorization in 2009, after almost 5 years of negotiation with by the residents with the municipal government (see Figure 4).

\section{Table 1 \\ Neighbourhood association in Pahandut District, Palangka Raya City, Indonesia}

\begin{tabular}{lcc}
\hline Village/ Kampung & $\begin{array}{c}\text { RT (Neigh- } \\
\text { bourhood } \\
\text { Organiza- } \\
\text { tion) }\end{array}$ & $\begin{array}{c}\text { RW (Com- } \\
\text { munity } \\
\text { Organiza- } \\
\text { tion) }\end{array}$ \\
\hline Pahandut & 96 & 26 \\
Panarung & 48 & 14 \\
Langkai & 67 & 17 \\
Tumbang Rungan & 2 & 1 \\
Tanjung Pinang & 10 & 4 \\
Pahandut Seberang & 9 & 2 \\
\hline
\end{tabular}

Source: BPS Palangka Raya City, 2009

Table 1. show Pahandut District has a legal administrative belongs to community association (RW) and neighbourhood association (RT) such as Kampung Pahandut have 96 RT and 26 RW, Kampung Panarung have 48 RT and 14 RT, Kampung Langkai have 67 RT and 17 RW, Kampung Tumbang Rungan have 2 RT and 1 RW, Kampung Tanjung Pinang have 10 RT and 4 RW, and Kampung Pahandut Seberang have 9 RT and 2 RW. It means that district of Pahandut have a stable of administrative to improve of infrastructure within of Kampung.

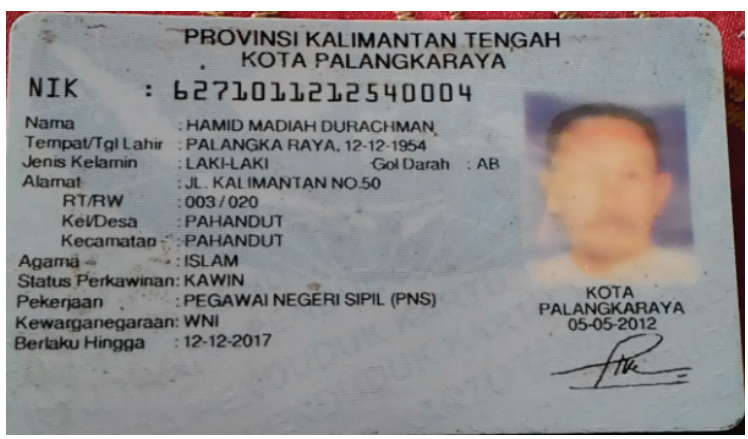

Figure 4. Recent format of a KTP based on the author KTP issued in 2012

(source: field survey, 2016)

Infrastructure

Physical infrastructure in Kampung Pahandut shows that collaboration between community's programs and the government programs appear in the form of road and drainage development, pathways improvement, social infrastructure development, garbage collection and management, kampung greenery movement, water supply connection, sanitation development, electricity connection, bridge construction, and recently public space development, intervention and extension of the government programs on physical improvements of the kampung of Palangka Raya indicate that kampungs are inclusively included in the developments maps of the city government. There is no any dichotomous model in the policy and development actions of Palangka Raya city.

In the development and improvement of roads and drainage, almost all kampung communities work together were the city government of Palangka Raya through block grant. This program is executed through stages of planning, financing, constructing, and maintaining. The maintenance of roads and drainage is usually done by the community, whereas for construction, due to it requires a technical skills is usually asked a technical assisstant from professional labors who have maturity and huge experiences in the technical construction. The mechanism used in this type of infrastructure development is that, people through a community meeting designed a proposal and submit to the city government.

Infrastructure did not obtain property titles. The KTP (ID cards) granted by the government has enabled residents to access state supported facilities, such as electricity connection (see Figure 5) and infrastructure upgrading.

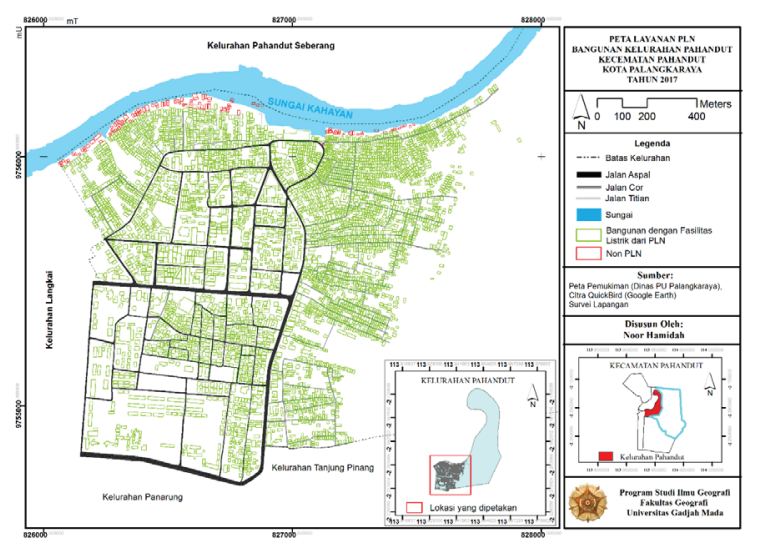

Figure 5. Map of electricity access for example legal electricity (green rectangle), illegal electricity (red rectangle)

(source: field observation, 2016 drawing by arc Map 3.10.1)

De Soto (1989) stated 'Traditional' means 'formal'. Kampung is a traditional, that is implies that in 'formal' development 
the state guarantees security of tenure in the form of legal title prior to the commencement of construction. Table 2 shown that ID-Card in Kampung Pahandut, this view of people of Kampung Pahandut have secure to live in Kampung. In these countries formal development is considered to be 'normal', while informal development is seen as 'abnormal'.

\section{Table 2}

ID Card of People in Kampung Pahandut, District of Pahandut, Palangka Raya City, Indonesia

\begin{tabular}{ccc}
\hline $\begin{array}{c}\text { Community Association } \\
\text { RW-21 }\end{array}$ & ID-Card & $\begin{array}{c}\text { no ID- } \\
\text { Card }\end{array}$ \\
\hline RT-1 & 26 & - \\
RT-2 & 23 & - \\
RT-3 & 27 & - \\
RT-4 & 24 & - \\
\hline
\end{tabular}

Source: BPS Palangka Raya City, 2009

Table 2 show people of Kampung Pahandut as a Indonesia citizen. It can be identified by ID card among of people of Kampung Pahandut. We asked of people from Kampung Pahandut by the sample of RW-21, that is all the people having ID Card, such as RT-1 has 26 ID card, RT-2 has 23 ID card, RT-3 has 27 ID card, and RT-4 has 24 ID card. It means the people of Kampung Pahandut recognition of Indonesia people and the people can access of infrastructure of electrical, water distribution, telephone, mobile phone, legal land (land certificate), etc.

Based on field survey we noted that kampung peoples argue without having formal or legal certificate, people can still have access to some basic services, particularly electricity and piped water. No matter what the legal status of land and buildings in a kampung may be, the PLN and PDAM will provide services, as long as people can pay the costs for such services. In other word, there is no practical benefit to having legal title to land and IMB, since basic services are provided by some government agencies regardless of the legal status of land and buildings.

The third type, can be obtained through by tenure status and the perceived permanence of building construction. In the case of the kampung in Indonesia, however, some ambiguities and inconsistencies exist concerning this issue. The first of these concerns the land issue. The problem in Palangka Raya is that land tenure is complicated by the fact that both the modern and the traditional systems are operating together simultaneously. In the kampung studied, the situation is further complicated by the fact that the land rented system is still widely practiced, as well as the fact that the inheritance of land does not usually follow a legal or formal procedure.

Therefore, it becomes very difficult to state clearly whether a kampung should be considered legal or illegal with respect to land tenure. fn the karnpung observed in this study, two different types of kampung can be distinguished. The first is kampung that are developed on public land without permission or legalization. This can be categorized as squatter settlements, since people invaded the land illegally and built on it without building permits. The second type of kampung is more complicated, as it contains both legal and illegal elements. In this kampung, some people clearly occupied the riverflat area without legal or formal permission from the government, and therefore could be considered illegal. However, most of the land in this kampung is legally owned by kampung people. Some plots of land may not be registered, some may be under dispute, and some may be held under the informal arrangement, but this does not mean that the kampung people do not have a right to their land.

The second ambiguity concerning illegality of the kampung relates to the building standards imposed by the government, or tlie building permit procedure (IMB). The IMB in Palangka Raya is based on Local Regulation No. 1, 1990 (Perda No. 1/1990). This regulation that all individuals and agencies should have an IMB before they can start construction; buildings without such permits can therefore be considered as illegal.

\section{Settlement}

In Palangka Raya, however, only about 30 per cent of the total number of buildings were constructed with IMB (Dinas Tata Kota Palangka Raya, 2016). Such a situation, of course, creates ambiguity and difficulties, since the majority of buildings in the city can technically be classified as illegal (see Table 3).

Table 3 shows that the relationship between property and tenure in the whole Kampung Pahandut has resulted in at least 2 type of tenure categories, first have building permit (legal building) and second have 
no building permit (illegal building). Based on field survey noted people in Kampung Pahandut have a reason why the people is not applying of IMB. IMB are very complicated as well as time and money-consuming. Building permit in a Kampung people views should theoretically $y$ be issued within a week, but in practice the procedure of organizing necessary back-up documentation and actual issuing of the building permit takes several month.

Table 3

\section{Building Permit (IMB) in Kampung Pahandut, District of Pahandut, Palangka Raya City, Indonesia}

\begin{tabular}{ccc}
\hline $\begin{array}{c}\text { Community } \\
\text { Association } \\
\text { RW-21 }\end{array}$ & IMB & No IMB \\
\hline RT-1 & 4 & 22 \\
RT-2 & 2 & 21 \\
RT-3 & 7 & 20 \\
RT-4 & 4 & 20 \\
\hline
\end{tabular}

Source: BPS Palangka Raya City, 2009

\section{Conclusions}

Kampung has its own long history as informal settlements. Kampung is lived on million people of the country live in. Kampung Pahandut, Palangka Raya city, Indonesia shows its capacity to integrate formal and informal activities both within the kampung itself and activities at city level. The integration of formal and informal activities in a kampung shows that dualistic approach and dichotomous model of urban policy have no their empirical arguments. The integration of formal and informal activities we call here as "a kampung is a compact kampung." The research comes out with three typologies of integration of "compact kampung". The first type of typology is shown by the present of "spatial" to "spatial" integration could be found in the openness of kampung to receive new development introduced in some kampung of Palangka Raya, as shown by new housing developments in the middle of kampung become; they use same access as used by the residents of kampung.

This research found three sub topics discusses: (1) security of tenure; (2) built form and territorial claim; and (3) mapping of morphological. Three sub topics will connect to physical integration of formal and informal in settlement (Doxiadis, 1968) focus on: (1) nature (land); (2) network (infrastructure); (3) shell (settlement). Physical integration found three important aspects to improve Kampung into urban planning, there are: (1) security of tenure; (2) built form and territorial claim; and (3) mapping of morphological.

Land. Field survey found that kampung people argue that is only through illegal mechanism that they can have access to resources, particularly land. Since the formal land market in Palangka Raya city does not work very well, and land prices and land speculation tend to be uncontrolled, there is only a limited chance for urban poor to get access to land through this formal market. In this situation, it is clear that the only alternative for them is to violate the law by the illegal invasion of public land.

Infrastructure. Field survey we noted that kampung peoples argue without having formal or legal certificate, people can still have access to some basic services, particularly electricity and piped water. No matter what the legal status of land and buildings in a kampung may be, the PLN and PDAM will provide services, as long as people can pay the costs for such services. In other word, there is no practical benefit to having legal title to land and IMB, since basic services are provided by some government agencies regardless of the legal status of land and buildings.

Settlement. Based on field survey noted people in Kampung Pahandut have a reason why the people is not applying of IMB. IMB are very complicated as well as time and moneyconsuming. Building permit in a Kampung people views should theoretically be issued within a week, but in practice the procedure of organizing necessary back-up documentation and actual issuing of the building permit takes several month.

\section{Acknowledgements}

The author would like to thanks to DIKTI gives funding to study in Faculty of Geography, Universitas Gadjah Mada, Universitas Palangka Raya, and also Students from Architecture of Department of Architecture, Palangka Raya University, who help much in conducting field work of this research in Palangka Raya City.

\section{References}

BPS Palangka Raya City. 2009. Kecamatan Pahandut dalam Angka 2009. Palangka Raya

Conzen, M. R. G., 1981, The Morphology of Towns in Britain During the Industrial 
Era. In The Urban Landscape: Historical Development and Management, edited by Whiteband, J.W.R. (London: Academic Press). Delanda, M., 2006, A New Philosophy of Society: Assemblage Theory and Social Complexity, (London: Continuum).

Davis, Mike, 2006, Planet of Slums, London, New York: Verso.

Deleuze, G. and Guattari, F., 1988, A Thousand Plateaus: Capitalism and Schizophrenia, (London: Athlone).

De Soto, H., 1989, The Other Path: The Invisible Revolution in The Third World, (New York: Harper \& Row).

De Soto, H., 2000, The Mystery of Capital: Why Capitalism Triumphs in the West and Fails Everywhere Else, (New York: Basic Books).

Dovey, K.,1999, Framing Places: Mediating Power in Built Form, (London: Routledge).

Groat, L. dan D. Wang. 2000. Architectural Research Methods, John Wiley\&Sons, NewYork.

Habraken, N. J., 2000, The Structure of the Ordinary: Form and Control in the Built Environment, (Cambridge: The MIT Press).

Moudon, A. V., 1997, Urban Morphology as an Emerging Interdisciplinary Field. In Urban
Morphology, Volume 1.

Payne, G., 1997, Urban Land Tenure and Property Rights in Developing Countries: A Review, (London: IT Publication/ODA).

Perlman, 2004, The Myth of Marginality: Urban Poverty and Politics in Rio De Janeiro. Berkeley: University of California Press.

Raharjo, 2010. Speculative Settlements: Built Form/Tenure Ambiguity in Kampung Development. In: Dissertation, The University of Melbourne, Australia.

Riwut, T. 1979. Kalimantan Menbangun. Penerbit PT. Jayakarta Agung offset, Jakarta.

Stryuk, Raymond J., Michael L. Hoffman, Harold M..Katsura. 1990. The Market of Shelter in Indonesia Cities. The Urban Institute Press, USA.

Setiawan, B., 1998, Local Dynamics in Informal Settlement Development: A Case Study of Yogyakarta Indonesia. In: Dissertation, The University of British Columbia, Amerika Serikat.

Law and Regulation.

Local Regulation (Perda, No. 1/ 1990). Palangka Raya Building Permit (IMB), Palangka Raya, Central Kalimantan Province, Indonesia. 